\title{
Prescribed medicines: who takes what?
}

\author{
ROBERT ANDERSON \\ From the Institute for Social Studies in Medical Care, London
}

SUMMARY The number of prescribed medicines dispensed in England and Wales increased by $21 \%$ between 1969 and 1977. Surveys carried out at the Institute for Social Studies in Medical Care have been used to compare the reported consumption of prescribed medicines in those two years. Although there were some changes in the distribution of prescribed medicines between age, sex, and social class groups, there did not appear to be an increase in the use of these medicines commensurate with the increase in the number dispensed. It is suggested that a growing proportion of people may be deciding not to take their medicines as instructed.

In England and Wales the total net ingredient cost of prescriptions increased by $386 \%$ between 1969 and 1977, while the average net ingredient cost of each prescription rose by less, $320 \%$. The difference was due to a $21 \%$ increase in the number of prescriptions dispensed, from 264 million in $1969^{1}$ to 318 million in 1977 (Department of Health and Social Security, personal communication). This means that the average number of prescribed medicines dispensed a person a year has increased from 5.6 to 6.6 in the same period. These increases have provoked a growing concern among the medical profession, the Government, and the public about the economic, social, and personal costs of drug use. General practitioners, who issue most of the prescriptions, 'have never been so interested in what they are prescribing and why'2; and observation by doctors of their own prescribing behaviour is one contribution to research, documenting and examining variations between GPs. ${ }^{3}$

The aim of this article is to document the pattern of medicine-taking in England and Wales in 1977, and to describe changes in the use of prescribed medicines between 1969 and 1977. It is based directly upon information from patients about their consumption of prescribed medication, rather than on data about the issuing or dispensing of prescriptions. Changes in the pattern of use of prescribed medicines, in age, sex, and social class groups, have been investigated by comparing results from surveys carried out at the Institute for Social Studies in Medical Care in $1969^{4}$ and $1977 .^{5}$

\section{Methods}

In 1977, 20 parliamentary constituencies in England and Wales were selected, after stratification, with probability proportional to their number of electors. Within each constituency 50 people were chosen by systematic random sampling from the electoral register. From this initial sampling of 1000, 836 people were successfully interviewed at home between March and July 1977. A structured questionnaire was used and three-quarters of the interviews lasted between one and two hours. Most of the questions were about experiences of, and attitudes towards, the care given by GPs; a small number of questions were about the use of prescribed medicines.

The people interviewed had distributions by age, sex, and marital status similar to those of the adult population in England and Wales. ${ }^{6}$ In the 1969 study people aged 18-20 were not on the electoral register, but they amounted to 4\% of respondents in 1977 . Their inclusion does not markedly affect any of the main variables, such as frequency of consultation.

In general, the studies carried out in 1969 and 1977 are comparable. Both involved an interview in the respondent's home and both were carried out in the second quarter of the year. In 1977, the people interviewed were living in England and Wales; the 1969 study included people on the electoral register in England, Wales, and Scotland. However, although there were differences in the populations from which the samples were taken, the distribution of respondents in the two studies by age, sex, and social class was similar.

The prescribed medicines were coded according to a modification of the new therapeutic classification devised by the Department of Health and Social Security. ${ }^{7}$ Oral contraceptives, in the endocrinological therapeutic class, were being used by 63 women, $30 \%$ of whom were also taking some other prescribed medicine. The women who were 
taking only the contráceptive pill confounded comparisons between medicine-takers and others because very few of them were likely to be using the pill for therapeutic reasons. Indeed, when we asked people to rate their health for their age as excellent, good, fair, or poor, $43 \%$ of women taking only an oral contraceptive, and $37 \%$ of those not taking any prescribed medicine, but only $18 \%$ * of people taking other prescribed medicines, rated their health as excellent. For these reasons, all analyses were carried out excluding oral contraceptives, and women whose only prescribed medicine was the contraceptive pill were classified as not taking any prescribed medicine. This modification was also made to the data collected in 1969.

\section{USE OF PRESCRIBED MEDICINES IN 1969 AND} 1977

People were asked whether, during the 14 days before the interview, they had taken any medicines, tablets, or ointments prescribed by a doctor, hospital, or clinic. In 1977,322 people (39\% of respondents) said they had taken some prescribed medicine. This was the same proportion as in 1969 , and, as Table 1 shows, there does not seem to have been any change between 1969 and 1977 in the proportions of people taking different numbers of medicines in combination. The average number of medicines taken by users was 2.0 in both studies.

\section{VARIATIONS IN THE USE OF PRESCRIBED MEDICINES}

Sex In 1977 , as in 1969 , women were more likely than men to be taking some prescribed medicine-45\% of women compared with $33 \%$ of men. There was no difference between male and female users in the number of medicines being taken. Age The difference between the proportion of men and that of women taking a prescribed medicine was significant, in 1977, only among people aged 18-54, and not among those aged 55 and over. Table 2 also shows that, in 1977, the medicine-taking of both

\footnotetext{
- In general, attention is not drawn to differences which might have occurred by chance five or more times in $\mathbf{1 0 0}$.
}

Table 1 Numbers of prescribed medicines taken during a two-week period in 1969 and in 1977

\begin{tabular}{lll}
\hline & $\begin{array}{l}1969 \\
(n=1412)\end{array}$ & $\begin{array}{l}1977 \\
(n=827) \\
\%\end{array}$ \\
Nos. of medicines & $\%$ & 61 \\
\hline None & 61 & 18 \\
One & 19 & 12 \\
Two & 10 & 5 \\
Three & 6 & 2 \\
Four & 2 & 2 \\
Five or more & 2 &
\end{tabular}

A small number of people from whom inadequate information was obtained have been excluded from this and subsequent tables. sexes varied little with age until the 55-64 group, in which the proportion taking a prescribed medicine increased substantially.

Thirty per cent of people aged 18-54 said they had taken some prescribed medicine in the last two weeks, but $56 \%$ of those aged 55 and over reported doing so; and those aged 55 and over were taking on average more than twice as many prescribed medicines a person $(1 \cdot 3$ compared with $0 \cdot 5)$.

In both 1977 and 1969 the differences between those under and those over 55 were more marked than the differences between the sexes. The age difference was more marked in 1977, mainly because of the increase from $36 \%$ (1969) to $51 \%$ (1977) in the proportion of men aged 55-64 taking a prescribed medicine. In general, a higher proportion of men aged 55 and over were taking a prescribed medicine in $1977(53 \%)$ than in $1969(43 \%)$. This increase may have been associated with developments in general practice, such as screening for hypertension.

There was only one other significant difference within age and sex groups between the two surveys - a fall in the proportion of people aged 75 and over who were taking prescribed medicines. The small number of people aged 75 and over in the 1977 study may have been unrepresentative with, for example, a consultation rate lower than expected from national figures. ${ }^{8}$ However, doctors may bee increasingly cautious about prescribing to those aged? 75 and over, because of increasing awareness of the problems, and difficulties, ${ }^{9}$ of drug use among the elderly.

Social Class In 1977, the proportion of people classified* as middle class or working class who were taking any prescribed medicines was similar (36\% and $41 \%$ respectively) but the mean number of prescribed medicines taken was higher among working class people (0.9) than among the middle class $(0 \cdot 7)$. There was no such difference in 1969 , and the difference in 1977 was a feature of the small number of medicines taken by people in Social Class I-out of 53 people, only 11 were taking a total of 15 prescribed medicines. But only $36 \%$ of Social Class I were women, and only $15 \%$ were aged 55 or over (comparable figures for all respondents were 51\% and $36 \%)$. Social class, age, and sex interacted to some degree, and were related to other variables such as marital status and household size. It seemed

\footnotetext{
- The classification is based on the Registrar General's classification of occupations, 1971. Men and single women have been classified on the basis of their present occupations if they were under 65 for men, or 60 for women, or their main occupations if they were older. Married and widowed women have been classified according to their husband's present, main, or last occupation.
} 
Table 2 Proportions (percentages) of people taking prescribed medicines during a two-week period in 1969 and 1977 by age and sex

\begin{tabular}{|c|c|c|c|c|c|c|c|c|c|c|c|c|}
\hline \multirow{3}{*}{$\begin{array}{l}\text { Age } \\
\text { groups } \\
\text { (years) }\end{array}$} & \multicolumn{6}{|l|}{1969} & \multicolumn{6}{|l|}{1977} \\
\hline & \multicolumn{2}{|l|}{ Men } & \multicolumn{2}{|l|}{ Women } & \multicolumn{2}{|l|}{ Both sexes } & \multicolumn{2}{|l|}{ Men } & \multicolumn{2}{|l|}{ Women } & \multicolumn{2}{|l|}{ Both sexes } \\
\hline & $\begin{array}{l}\text { No. } \\
(=100 \%)\end{array}$ & $\begin{array}{l}\text { (\% } \\
\text { taking) }\end{array}$ & $\begin{array}{l}\text { No. } \\
(=100 \%)\end{array}$ & $\begin{array}{l}\text { (\% } \\
\text { taking) }\end{array}$ & $\begin{array}{l}\text { No. } \\
(=100 \%)\end{array}$ & $\begin{array}{l}\text { (\% } \\
\text { taking) }\end{array}$ & $\begin{array}{l}\text { No. } \\
(=100 \%)\end{array}$ & $\begin{array}{l}\text { (\% } \\
\text { taking) }\end{array}$ & $\begin{array}{l}\text { No. } \\
(=100 \%)\end{array}$ & $\begin{array}{l}\text { (\% } \\
\text { taking) }\end{array}$ & $\begin{array}{l}\text { No. } \\
(=100 \%)\end{array}$ & $\begin{array}{l}\text { (\% } \\
\text { taking) }\end{array}$ \\
\hline $\begin{array}{l}18-24 \\
25-34 \\
35-44 \\
45-54 \\
55-64 \\
65-74 \\
75+\end{array}$ & $\begin{array}{r}35^{*} \\
107 \\
148 \\
131 \\
118 \\
88 \\
33\end{array}$ & $\begin{array}{l}(11) \\
(21) \\
(26) \\
(30) \\
(36) \\
(40) \\
(73)\end{array}$ & $\begin{array}{r}46^{*} \\
123 \\
141 \\
138 \\
140 \\
106 \\
54\end{array}$ & $\begin{array}{l}(43) \\
(41) \\
(40) \\
(33) \\
(50) \\
(58) \\
(70)\end{array}$ & $\begin{array}{r}81^{*} \\
230 \\
289 \\
269 \\
258 \\
194 \\
87\end{array}$ & $\begin{array}{l}(30) \\
(32) \\
(33) \\
(32) \\
(43) \\
(49) \\
(71)\end{array}$ & $\begin{array}{l}45 \\
86 \\
78 \\
66 \\
67 \\
41 \\
21\end{array}$ & $\begin{array}{l}(22) \\
(21) \\
(21) \\
(29) \\
(51) \\
(56) \\
(57)\end{array}$ & $\begin{array}{l}46 \\
86 \\
61 \\
63 \\
67 \\
60 \\
41\end{array}$ & $\begin{array}{l}(37) \\
(35) \\
(36) \\
(38) \\
(55) \\
(62) \\
(54)\end{array}$ & $\begin{array}{r}91 \\
172 \\
139 \\
129 \\
134 \\
101 \\
62\end{array}$ & $\begin{array}{l}(30) \\
(28) \\
(27) \\
(34) \\
(53) \\
(59) \\
(55)\end{array}$ \\
\hline All ages & 662 & (31) & 750 & (46) & 1412 & (39) & 404 & (33) & 424 & (54) & 828 & (39) \\
\hline
\end{tabular}

- People aged 21-24 only.

Table 3 Frequency of consultation and medicine-taking by age, sex, and social class

\begin{tabular}{|c|c|c|c|c|c|c|c|c|}
\hline & \multicolumn{4}{|l|}{$M E N$} & \multicolumn{4}{|c|}{ WOMEN } \\
\hline & \multicolumn{2}{|l|}{$18-54^{*}$} & \multicolumn{2}{|c|}{55 and over } & \multicolumn{2}{|l|}{$18-54^{*}$} & \multicolumn{2}{|c|}{55 and over } \\
\hline & $\begin{array}{l}\text { Middle } \\
\text { class }\end{array}$ & $\begin{array}{l}\text { Working } \\
\text { class }\end{array}$ & $\begin{array}{l}\text { Middle } \\
\text { class }\end{array}$ & $\begin{array}{l}\text { Working } \\
\text { class }\end{array}$ & $\begin{array}{l}\text { Middle } \\
\text { class }\end{array}$ & $\begin{array}{l}\text { Working } \\
\text { class }\end{array}$ & $\begin{array}{l}\text { Middle } \\
\text { class }\end{array}$ & $\begin{array}{l}\text { Working } \\
\text { class }\end{array}$ \\
\hline $\begin{array}{l}1969 \\
\text { Mean number of GP consultations } \\
\text { in last } 12 \text { months }{ }^{* *} \\
\text { Proportion taking } \\
\text { a prescribed medicine }\end{array}$ & $\begin{array}{l}2 \cdot 2 \\
27 \%\end{array}$ & $\begin{array}{l}2.5 \\
23 \%\end{array}$ & $\begin{array}{l}3.0 \\
41 \%\end{array}$ & $\begin{array}{l}2.9 \\
44 \%\end{array}$ & $\begin{array}{l}3.0 \\
37 \%\end{array}$ & $\begin{array}{l}3.9 \\
40 \%\end{array}$ & $\begin{array}{l}3.6 \\
59 \%\end{array}$ & $\begin{array}{l}4 \cdot 2 \\
53 \%\end{array}$ \\
\hline No. of people $(=100 \%)$ & 148 & 258 & 85 & 142 & 179 & 235 & 98 & 179 \\
\hline $\begin{array}{l}1977 \\
\text { Mean number of GP consultations } \\
\text { in last } 12 \text { months** } \\
\text { Proportion taking } \\
\text { a prescribed medicine }\end{array}$ & $\begin{array}{l}2 \cdot 3 \\
21 \%\end{array}$ & $\begin{array}{l}3.2 \\
26 \%\end{array}$ & $\begin{array}{l}3.0 \\
46 \%\end{array}$ & $\begin{array}{l}4.9 \\
57 \%\end{array}$ & $\begin{array}{l}4 \cdot 2 \\
37 \%\end{array}$ & $\begin{array}{l}4 \cdot 3 \\
36 \%\end{array}$ & $\begin{array}{l}3.7 \\
56 \%\end{array}$ & $\begin{array}{l}3.9 \\
58 \%\end{array}$ \\
\hline No. of people $(=100 \%)$ & 119 & 152 & 48 & 79 & 116 & 125 & 61 & 102 \\
\hline
\end{tabular}

appropriate, therefore, to consider the use of prescribed medicines by age, sex, and social class together (Table 3)*

This Table shows that the increase over time in the use of prescribed medicines by men aged 55 and over related mainly to working class men, whose estimated annual consultation rate had increased from 2.9 in 1969 to 4.9 in 1977 . There were other social class differences in consultation rates, both between middle class and working class men in 1977 , and between younger middle class women in 1969 and 1977 , which were not reflected in differences in the reported use of prescribed medicines. Clearly, variation in the frequency of consultations was not, by itself, an adequate indicator of differences in the use of prescribed medicines. This is not surprising

- Age groups were divided into those under and over 55, since the proportion of males in our sample fell markedly in the 55-64 age group; and the proportion of people who were middle class fell from $47 \%$ of people aged $45-54$ to $36 \%$ of people aged 55-64. considering that the motives for consultation may differ greatly between social groups and over time in the same group. Consultations for sickness certification, family planning advice, and depression can be expected to have different outcomes in terms of prescribing. Furthermore, other authors have referred to the many factors influencing the doctor's decision to precribe, ${ }^{40^{12}}$ as well as the patient's decision to have the medicine dispensed. ${ }^{13}$

WHAT SORT OF MEDICINES?

The proportions taking different classes of medicines varied, as expected, with sex, age, and, to a lesser degree, with social class.

Table 4 shows the proportions of men and women taking medicines in each therapeutic class. It was not possible to compare these results with those of 1969 , because the classification of medicines was different.

Women were more likely than men to be taking psychotropic drugs, other preparations acting on the 
Table 4 Proportions of men and women taking prescribed medicines in each therapeutic class (1977)

\begin{tabular}{|c|c|c|c|}
\hline Therapeutic class & $\begin{array}{l}\text { Men } \\
(n=399) \\
\%\end{array}$ & $\begin{array}{l}\text { Women } \\
(n=420) \\
\%\end{array}$ & $\begin{array}{l}\text { Both } \\
\text { sexes } \\
(n=819) \\
\%\end{array}$ \\
\hline $\begin{array}{l}\text { Psychotropic } \\
\text { Other nervous system } \\
\text { Gastrointestinal } \\
\text { Cardiovascular or diuretic } \\
\text { Respiratory or allergic } \\
\text { Rheumatic } \\
\text { Anti-microbial } \\
\text { Endocrinological* } \\
\text { Nutrition or blood } \\
\text { Skin, eyes or } \\
\text { mucous membrane } \\
\text { Other }\end{array}$ & $\begin{array}{l}8 \\
6 \\
4 \\
8 \\
6 \\
4 \\
5 \\
3 \\
2 \\
6 \\
-\end{array}$ & $\begin{array}{r}15 \\
10 \\
4 \\
11 \\
5 \\
6 \\
4 \\
4 \\
5 \\
\\
5\end{array}$ & $\begin{array}{r}12 \\
8 \\
4 \\
10 \\
6 \\
5 \\
4 \\
4 \\
3 \\
\\
5\end{array}$ \\
\hline
\end{tabular}

* Excludes oral contraceptives, taken by $15 \%$. of all women.

central nervous system (CNS)-nearly all of which were analgesics-and medicines affecting nutrition or blood. Drugs in two therapeutic classes, the psychotropic drugs and those acting on the cardiovascular system, or diuretics, were each being taken by $10 \%$ or more of people aged 18 or over. Moreover, drugs in these two classes dominated the medicine-taking of people aged 55 and over. Psychotropic drugs, and diuretics or medicines acting on the cardiovascular system, together accounted for half of the medicines being taken by people aged 55 and over. One-fifth of them were taking psychotropic drugs, and nearly a quarter were using diuretics or medicines acting on the cardiovascular system. In all therapeutic classes, except the anti-microbial, the nutritional, and the composite class for skin, eyes, and mucous membranes, more people aged 55 and over were taking some prescribed medicine. Table 5 shows that this age difference was marked in slightly different ways for men and women. People of both sexes aged 55 and over were more likely than younger people to be taking psychotropic and cardiovascular drugs; older men were more likely than men aged 18-54 to be taking endocrinological and respiratory or allergic drugs; and older women were more likely than women aged $18-54$ to be taking gastrointestinal and rheumatic medicines.

There were few sex differences within age groups. Women aged 18-54 were more likely than men of the same age to be taking medicines in the 'other central nervous system' class-possibly women using analgesics for relief of menstrual pain contributed to this difference. Among people aged 55 or over, the only significant difference was the greater probability of men taking drugs for infections.

Working class people aged 55 and over were more likely to be taking medicines for rheumatism: $13 \%$ compared with only $4 \%$ of middle class people of similar ages. This was partly a reflection of the higher rate of chronic (long-standing) illness among the working class. ${ }^{14}$ Another feature of chronic illness is the use of drugs in combination, particularly psychotropic drugs used as an adjunct to other drugs treating somatic conditions. ${ }^{15}$ Psychotropic drugs were being used by $28 \%$ of those taking prescribed medicines for rheumatism, $33 \%$ of those taking them for nutrition or blood, and $37 \%$ of people using diuretics or medicines acting on the cardiovascular system. Altogether, more than two-fifths of medicine-takers had used prescribed medicines from at least two therapeutic classes in the two weeks before our interview.

The pattern of use of CNS drugs by women aged 55 and over appeared to be different for middle class and working class women. Similar proportions of both groups were taking some preparation acting on the CNS; however, all the older middle class women who were taking some CNS drug were taking a psychotropic drug, whereas nearly half the working class women were taking some other medicine acting on the CNS but not a psychotropic drug. In 1969, Dunnell and Cartwright ${ }^{4}$ found that, in general, more middle class than working class people had used

Table 5 Proportions taking medicines in each therapeutic class by age, sex, and social class

\begin{tabular}{|c|c|c|c|c|c|c|c|c|}
\hline \multirow[b]{3}{*}{ Therapeutic class } & \multicolumn{4}{|l|}{$M E N$} & \multicolumn{4}{|l|}{ WOMEN } \\
\hline & \multicolumn{2}{|l|}{$18-54$} & \multicolumn{2}{|c|}{55 and over } & \multicolumn{2}{|l|}{$18-54$} & \multicolumn{2}{|c|}{55 and over } \\
\hline & $\begin{array}{l}\text { Middle } \\
\text { class } \\
(n=119) \\
\%\end{array}$ & $\begin{array}{l}\text { Working } \\
\text { class } \\
(n=147) \\
\%\end{array}$ & $\begin{array}{l}\text { Middle } \\
\text { class } \\
(n=46) \\
\%\end{array}$ & $\begin{array}{l}\text { Working } \\
\text { class } \\
(n=76) \\
\%\end{array}$ & $\begin{array}{l}\text { Middle } \\
\text { class } \\
(n=113) \\
\%\end{array}$ & $\begin{array}{l}\text { Working } \\
\text { class } \\
(n=122) \\
\%\end{array}$ & $\begin{array}{l}\text { Middle } \\
\text { class } \\
(n=60) \\
\%\end{array}$ & $\begin{array}{l}\text { Working } \\
\text { class } \\
(n=100) \\
\%\end{array}$ \\
\hline Psychotropic & 4 & 6 & 17 & 14 & 8 & 11 & 30 & 19 \\
\hline Other nervous system & 4 & 4 & 7 & 11 & 8 & 11 & 3 & 18 \\
\hline Gastrointestinal & 1 & 5 & 7 & 4 & 3 & 2 & 7 & 7 \\
\hline Cardiovascular or diuretic & 3 & 1 & 17 & 22 & 4 & 2 & 23 & 25 \\
\hline Respiratory or allergic & 3 & 3 & 13 & 13 & 6 & 2 & 5 & 7 \\
\hline Rheumatism & 3 & 3 & - & 9 & 3 & 1 & 7 & 15 \\
\hline Anti-microbial & 2 & 5 & 15 & 4 & 5 & 5 & 2 & 2 \\
\hline Endocrinological & - & 3 & 11 & 4 & 3 & 2 & 3 & 8 \\
\hline Nutrition or blood & 1 & 1 & 7 & 3 & 4 & 4 & 5 & 4 \\
\hline Skin, eyes, or mucous membrane & 5 & 5 & 7 & 7 & 4 & 10 & 2 & 3 \\
\hline
\end{tabular}


sedatives in the previous two weeks. The authors suggested that the difference lay in the consulting room; 'Once there, middle class patients may communicate their demands and anxieties more effectively to their doctor, or the doctor may respond to their symptoms differently'.

\section{Discussion}

The proportion of people reporting the use of prescribed medicines in a two-week period was the same in 1977 as it had been in 1969, although, according to official figures, the number of medicines dispensed was $21 \%$ higher in 1977 than it was in 1969.

Oral contraceptives are included in the national figures; their inclusion in the survey data produced a small increase in the proportion of people reporting the use of a prescribed medicine, in the previous two weeks, from $41 \%$ in 1969 to $44 \%$ in 1977 . However, prescriptions for oral contraceptives represented less than $2 \%$ of the total number dispensed in 1977 (DHSS, personal communication), so that very little of the total increase in the number of prescriptions dispensed between 1969 and 1977 can be attributed to them. The national data exclude medicines dispensed directly by hospitals, and a decrease in prescribing from this source may account for some of the apparent shortfall in the use of prescribed medicines. However, the number of people using medicines dispensed in hospitals is probably small compared with the number using medicines dispensed by pharmacists, and the effect of any diminished prescribing in the hospital sector would be limited. The relationship between medicines dispensed in hospitals and outside needs further investigation.

The number of people who could possibly be taking a prescribed medicine at any one time is related to the number of prescriptions dispensed in a year, but this relationship is mediated by factors such as the average quantity of medicine in each prescription, the scale of multiple medication, and the distribution of medicine-taking over the year, or its seasonality.

The length of time for which a prescription is issued may be important if, for example, doctors have shortened the average number of days for which a prescription is designed-then the number of prescriptions dispensed could increase without any change in the proportion of people taking prescribed medicines. Such an increase would have resulted in a larger proportion of short-term prescriptions in the 1977 sample, compared with 1969. However, as reported elsewhere ${ }^{16}$ there was no change between 1969 and 1977 in the number of prescriptions people said they had received for particular drugs, or in the length of time for which these drugs had been taken. As Table 1 shows, there was no change between 1969 and 1977 in the scale of multiple medication.

It is unlikely that there are large effects due to the seasonality of illnesses presented to doctors, since both studies were carried out at the same time of year. There are no obvious reasons why, in reporting their use of prescribed medicines, people should be any more forgetful or less inclined to report medicine use in 1977 than they were in 1969. It is possible that there has been some increase in use of prescribed medicines by children, who were excluded from both studies, but DHSS data ${ }^{17}$ show that in both 1969 and 1976 a similar proportion of prescriptions (11\%) went to children exempted from payment.

Since other explanations seem inadequate, it is suggested that some of the discrepancy between official figures on the number of medicines dispensed and our survey data on the use of precribed medicines may be due to an increase in the proportion of people not taking their medicines as directed or not at all. Stimson ${ }^{18}$ has emphasised that the response of people to their dispensed medication is affected by their ideas about and attitudes to the use of medicines. A comparison of general practice in 1977 and $1964^{8}$ shows that people consulting a doctor in 1977 were less likely to expect a prescription but the proportion of consultations at which a prescription was issued had not changed. In addition, a higher proportion of people in 1977 were critical of their own doctors for being too inclined to give a prescription. In such circumstances it would not be surprising if more people were deciding against taking their medicines as instructed.

A recent survey ${ }^{7}$ of people to whom prescriptions were dispensed reveals a pattern by age and sex generally similar to that reported here on the use of prescribed medicines. However, Skegg et al found that one-third of women aged 45-59 received a psychotropic drug during the year, but this high proportion is not reflected in data from the present study on use of psychotropic drugs by women aged 45-54. The reason may be that women of menopausal age are sensitive about declaring their use of supportive psychotropic drugs, or that such drugs are prescribed only for short periods in this age group. Alternatively, it is possible that some women for whom psychotropic drugs are prescribed feel they have been too readily labelled as having 'depression associated with the menopause' and consequently they are not taking the drugs. Thus the different result in this study and that by Skegg et al may be due to differences in method, or reveal a real difference between drug dispensing and drug use in this age and sex group. If an increase in 'non-compliance' can be 
confirmed more directly elsewhere, it will be important to document how this varies with the characteristics and attitudes of both doctors and their patients. An increase in 'non-compliance' implies a greater waste of resources, and, from the professional viewpoint at least, less efficient treatment.

I thank Ann Cartwright and also Ruth Cooperstock, Karen Dunnell, Mims Orleans, Jasper Woodcock, Alison Venning, Christopher Smith, Michele Hudson, Joanne Abel, Moira Purves, other colleagues and members of the Institute's Advisory Committee, and the people who answered the questions. The Department of Health and Social Security funded the study.

Reprints from R. Anderson, Esq., Institute for Social Studies in Medical Care, 14 South Hill Park, London NW3 2SB.

\section{References}

${ }^{1}$ Department of Health and Social Security. Health and Personal Social Services Statistics for England 1974. London: HMSO, 1974.

${ }^{2}$ Anonymous. Prescribing in general practice.J $R$ Coll Gen Pract 1978; 28: 515.

${ }^{3}$ Taylor RJ. General practitioner prescribing. J R Coll Gen Pract 1977; 27: 79-82.
${ }^{4}$ Dunnell K, Cartwright A. Medicine Takers, Prescribers and Hoarders. London: Routledge and Kegan Paul, 1972.

${ }^{5}$ Cartwright A, Anderson R. Patients and their Doctors in 1977. Occasional Paper No. 8. London: J R Coll Gen Pract, 1979.

${ }^{6}$ Central Statistical Office. Annual Abstract of Statistics. London: HMSO, 1979.

${ }^{7}$ Skegg DCG, Doll R, Perry J. Use of medicines in general practice. Br Med J 1979; i: 1561-3.

${ }^{8}$ Cartwright A, Anderson R. General Practice Revisited. London: Tavistock Press (in press).

9 Jenkins GHC. Drug compliance and the elderly patient. Letter. Br Med J 1979; i: 124.

${ }^{10}$ Howie JGR. Clinical judgment and antibiotic use in general practice. $\mathrm{Br}$ Med J 1976; ii: 1061-4.

${ }^{11}$ Raynes NV. Factors affecting the prescribing of psychotropic drugs in general practice consultations. Psychol Med 1979; 9: 671-9.

${ }^{12}$ Cartwright A. Prescribing and the relationship between patients and doctors. In: Cooperstock $\mathbf{R}$, ed. Social Aspects of the Medical Use of Psychotropic Drugs. Canada: Addiction Research Foundation of Ontario, 1974: 63-74.

${ }^{13}$ Waters WHR, Gould NV, Lunn JE. Undispensed prescriptions in a mining general practice. $\mathrm{Br}$ Med $\mathrm{J}$ 1976; i: 1062-3.

${ }^{14}$ Office of Population Censuses and Surveys. General Household Survey 1977. London: HMSO, 1979.

${ }^{15}$ Williams P. Physical ill-health and psychotropic drug prescriptions-a review. Psychol Med 1978; 8: 683-93.

${ }^{16}$ Anderson $\mathrm{R}$. The use of repeatedly prescribed medicines. J R Coll Gen Pract 1980; 30: 609-13.

${ }^{17}$ Department of Health and Social Security. Annual Report 1977. London: HMSO, 1978.

${ }^{18}$ Stimson GV. Obeying doctor's orders: a view from the other side. Soc. Sci Med 1974; 8: 97-104. 